\title{
Nursing care practices for people with Chronic Noncommunicable Diseases
}

\author{
Práticas de cuidado dos enfermeiros a pessoas com Doenças Crônicas Não Transmissíveis
}

Las prácticas de cuidado de los enfermeros a las personas con Enfermedades Crónicas no Transmisibles

\section{Renata Machado Becker', Ivonete Teresinha Schülter Buss Heidemann', Betina Horner Schlindwein Meirelles', Maria Fernanda Baeta Neves Alonso da Costa', Fabiano Oliveira Antonini', Michelle Kuntz Durand' \\ ' Universidade Federal de Santa Catarina. Florianópolis, Santa Catarina, Brazil.}

\section{How to cite this article:}

Becker RM, Heidemann ITSB, Meirelles BHS, Costa MFBNA, Antonini FO, Durand MK. Nursing care practices for people with Chronic Noncommunicable Diseases. Rev Bras Enferm [Internet]. 2018;71(Suppl 6):2643-9. [Thematic Issue: Good practices in the care process as the centrality of the Nursing] DOI: http://dx.doi.org/10.1590/0034-7167-2017-0799

\author{
Submission: 12-12-2017Ａpproval: 03-16-2018
}

\section{ABSTRACT}

Objective: To understand care practices for people with Chronic Noncommunicable Disease, developed by Primary Health Care nurses in a municipality in southern Brazil. Method: Qualitative study, developed through the Discourse of the Collective Subject. Twenty-three nurses from the Family Health Strategy participated. Data were collected through semi-structured interviews and analyzed by the health promotion framework. Results: Nurses care practices for people with chronic disease present themselves through the home visit, individual care and collective care. These, eventually, have an extended character, advocating the promotion of health, at other times it is restrictive, returning to be a traditional and biologicalist practice. Final considerations: The nurse acts in a diversified way in this field, being present in the lives of people with chronic diseases. However, it is necessary to move forward, especially in the search for the constant and continuous development of an extended and welcoming care practice.

Descriptors: Nursing Care; Primary Health Care; Nursing; Chronic Disease; Health Promotion.

\section{RESUMO}

Objetivo: Compreender as práticas de cuidado a pessoas com Doença Crônica Não Transmissível, desenvolvidas pelos enfermeiros da Atenção Primária à Saúde de um município do sul do Brasil. Método: Estudo qualitativo, desenvolvido por meio do Discurso do Sujeito Coletivo. Participaram 23 enfermeiros da Estratégia Saúde da Família. Os dados foram coletados por entrevistas semiestruturadas e analisados pelo referencial da promoção da saúde. Resultados: As práticas de cuidado dos enfermeiros a pessoas com doença crônica se apresentam pela visita domiciliar, atendimento individual e atendimento coletivo. Estas, eventualmente, têm caráter ampliado, preconizando a promoção da saúde, em outros momentos se revela restritiva, voltando a ser uma prática tradicional e biologicista. Considerações finais: $\mathrm{O}$ enfermeiro atua de modo diversificado neste campo, mostrando-se presente na vida das pessoas com doença crônica. Contudo, é preciso avançar, principalmente na busca pelo desenvolvimento constante e contínuo de uma prática de cuidado ampliada e acolhedora.

Descritores: Cuidados de Enfermagem; Atenção Primária à Saúde; Enfermagem; Doença Crônica; Promoção da Saúde.

\section{RESUMEN}

Objetivo: Comprender las prácticas de cuidado a las personas con Enfermedades Crónicas no Transmisibles, desarrolladas por los enfermeros de la Atención Primaria a la Salud de un municipio del sur del Brasil. Método: Estudio cualitativo, desarrollado por medio del discurso del sujeto colectivo. Participaron 23 enfermeros de la Estrategia Salud de la Familia. Los datos fueron recolectados por entrevistas semiestructuradas y analizados por el referencial de la promoción de la salud. Resultados: Las prácticas de cuidado de los enfermeros a las personas con enfermedad crónica se presentan por la visita domiciliaria, la atención individual y la atención colectiva. Estas, eventualmente, tienen un carácter ampliado, preconizando la promoción de la salud. En otros momentos, se revela restrictiva, volviendo a ser una práctica tradicional y biologicista. Consideraciones finales: El enfermero actúa de modo diversificado en este campo, mostrándose presente en la vida de las personas con enfermedades crónicas. Sin embargo, hay que avanzar, principalmente en la búsqueda por el desarrollo constante y continuo de una práctica de cuidado ampliada y acogedora.

Descriptores: Cuidados de Enfermería; Atención Primaria a la Salud; Enfermería; Enfermedades Crónicas; Promoción de la Salud. 


\section{INTRODUCTION}

The Family Health Strategy (FHS) is the key point of Primary Health Care (PHC), especially for reorganizing the care model, through the performance of a multiprofessional team ${ }^{(1)}$. Within this team, the nurse has proved essential for the expansion and consolidation of the $\mathrm{FHS}^{(1-2)}$.

This professional is committed to actions and practices of education, health promotion and prevention of diseases/diseases of the community, in search of a better quality of life, critical and constructive empowerment ${ }^{(2-3)}$. These characteristics are essential for the health care of people with Chronic Noncommunicable Disease (NCDs), since health promotion actions provide a look at the disease, avoid complications and improve the quality of life of people, as well as families ${ }^{(4)}$. NCDs, in turn, are considered one of the main health problems in the world, due to their magnitude, thus requiring a response from all sectors of society ${ }^{(5)}$.

NCDs present an alarming epidemiological profile and generate a high number of premature deaths, loss of quality of life, high degree of limitation of people for their usual work and leisure activities, negative economic impact on families, communities and society, aggravating social inequities ${ }^{(6)}$. The growth of the NCDs brings a new focus to the PHC, which needs to review practices that put the centrality in the disease that should be cured. In other words, it is necessary to have discussions about health practices and work processes, especially in the scope of $\mathrm{PHC}^{(7)}$.

In this field, health promotion is a cost-effective and impactful population intervention in the face of this problem, since it is a practice that prioritizes the expanded concept of the health/ disease process, as well as its innumerable determinants ${ }^{(8)}$.

In addition to these notes, the national scientific production on the care of nurses at PHC presents itself as a debate to be built, due to the reduced production on the subject, indicating the need to advance the articulation of the practices carried out by these professionals, and in the reflection on care in this field of action, which is the gateway to the Brazilian Unified Health System (SUS- Sistema Único de Saúde) ${ }^{(9)}$.

Therefore, the performance of this study is justified by the need to understand how these professionals are performing care with people with NCDs, since this is a still scarce area of scientific knowledge. In this way, its importance lies in revealing this production.

In this context, it is questioned, how do care practices for people with NCDs are developed by the PHC nurses of a municipality of the south of Brazil?

\section{OBJECTIVE}

This study aims to understand the care practice for people with Chronic Noncommunicable Disease, developed by Primary Health Care nurses in a municipality in southern Brazil.

\section{METHOD}

\section{Ethical aspects}

This study was approved by the Research Ethics Committee of the Universidade Federal de Santa Catarina. All participants signed the Informed Consent Term, as required by Resolution
466, dated December 12, 2012, of the National Health Council (Conselho Nacional de Saúde), which governs research involving human beings, as well as obeying all legal ethical precepts, which involves researches with human beings.

Theoretical-methodological framework and type of study

It is a qualitative study, developed with the methodology of the Discourse of the Collective Subject (DCS).

\section{Study setting}

The data collection site was $23 \mathrm{PHC}$ health centers in a city in the south of Brazil, chosen by means of an electronic lottery. The municipality considers PHC as the communication center of its network of care, being organized as the FHS model. That is, it counts on multiprofessional teams that are responsible for the follow-up and coordination of the care to a certain population.

\section{Data source}

The research subjects were 23 nurses, one from each health center selected. The inclusion criteria were: to be a nurse, registered and active in a FHS team; and as exclusion criterion: absence of professional experience in the PHC area of at least six months of performance or being away for vacation or leave. In order to choose these professionals, the health center coordinator indicated and invited a professional to the research, according to the availability of time in the agenda, without having a specific criterion for the choice, only meeting the criteria of inclusion and exclusion of the research, and no one refused to participate.

\section{Collection and data organization}

For the data collection, individual interviews were carried out, from June to August, 2016, using a semi-structured script. This included questions about the sociodemographic and professional characteristics of the participants and about their work in PHC with people with NCDs. The interviews, recorded and transcribed in full, being guaranteed the anonymity of the participants, were previously scheduled via the unit's coordinator and occurred in the health center itself, in an office room, where it was possible to maintain a quiet and private environment.

Data were organized from the DCS, a set of data that use the statements and identify the methodological figures such as key expressions, central ideas and anchorages to understand the linguistic manifestations of thoughts about a central idea ${ }^{(10-11)}$. Therefore, detailed readings of the responses of each participant were processed in order to identify the key expressions, that is, to determine the essence of the testimony. With the definition of the key expressions, we proceeded to the stage of identifying the central ideas, which correspond to the synthetic expressions that really convey the meaning of each discourse. Finally, the key expressions that had the same central idea, generating the DCS, were merged. For this training, DCSsoft software was used, which aims to make feasible the research developed by this methodology, leaving them more agile, practical, providing the reach and the validity of the results ${ }^{(11)}$.

\section{Data analysis}

The data were analyzed using the theoretical framework of health promotion. For health promotion, it is understood the 
"process of empowering individuals and the community to act in the improvement of their quality of life and health, including a greater participation in the control of this process" ${ }^{\prime \prime 2}$. From this understanding, it is perceived that health promotion practices constitute a possibility to reinforce broader forms of health intervention, focusing on the aspects that determine the health/disease process. In addition, these practices are important for the theoretical construction of collective health, valuing universality and comprehensiveness, prioritizing the collective approach, aiming to reduce social inequalities, empowerment and autonomy of people, social participation and knowledge multi-professional ${ }^{(13)}$.

\section{RESULTS}

\section{Profiling of study subjects}

The profiling of participants showed that 21 people were female and two were male. The age ranged from 27 to 57 years, and the age group with the largest number of participants was between 31 and 45 years $(69.56 \%)$. As for the schooling level, 21 had some type of specialization; one had a master's degree; and one doctorate. In relation to the time of professional performance in the PHC, it corresponded from three to 24 years, and the range from six to 15 years was the one of greater prevalence, making a total of 14 nurses.

\section{Discourses of the Collective Subject - DCS}

Emphasis was given to the analysis of the perception of nurses working at the FHS about care practices for people with NCDs. The central ideas presented in Table 1 were identified, as well as their respective frequency of appearance.

Central idea A: Work through home visit

I do a home visit for specific people who are those who have criteria, elderly, or really very old, or bedridden, who cannot come in the unit, for the sake of wandering. So we end up going to the house. They usually contemplate this type of health problem, patients who have some difficulty. In addition, my area of coverage is far, $90 \%$ have to go by car, so we visit more of the bedridden people who usually have hypertension or diabetes, because of the car; we go in those who have more physical limitations. The routine visit is usually not only chronic, it should have some more comorbidity; there is no reserve for this. We do together, physician and nurse, we have a table, not to go only when the patient seeks, not to miss the routine of monitoring. We go to the house for various approaches, and we can arrange all this in area meetings, which are the visits to be made and direct to those most needed. (DCS1)

Central idea B: Work through individual care

We changed the appointment/host system, there are no longer schedules. The person arrives and all will be met, we started a short time ago, and we are successful. If it is a case of a nurse,
I will answer, if it is for the physician, we will make the referral, if we need to carry out appointments. With the protocol of hypertension and diabetes, I make the appointment, and then reverse, consulted with me this time, the next is with the physician. Therefore, I do not have a schedule for scheduled appointments, it is more in the spontaneous demand. I make regular appointments, according to the need, respecting the protocol. My schedule is free, for those who need to talk or consult with the nurse, there is no limit. In the queries of spontaneous demand, the general care, feeding, medicine, hypertensive and diabetic are addressed. The closest I get are insulin-dependent diabetics, perhaps because of inputs, reports, contact is more frequent. So, this is the group that I am most able to work after the nursing protocol. In the host $I$ already board on the exams, the use of the medicines, who helps. They can reach the reception desk and make the appointment, although they still do not look for much, we also dial by phone or by email. Therefore, we organize our work process, the schedules, half host and half scheduling. I have fixed hours of service to people from risk groups, like elderly, hypertensive, diabetic and I make requests of spontaneous demand during the day. In the host he brings the demand, we do care guidelines, we do a lot of health education and with the protocol I think it will improve the teamwork, physician and nurse, to serve these patients. (DCS 2)

Central idea C: Work through collective service

I act with the group of diabetic dependent insulin, they get together with NASF residents, the NASF itself and the staff in general. I do a job with them, deliver the tapes, make guidelines, examine the feet and there is a schedule of lectures with professionals. We also have a smoking group, where chronic patients are included, mainly hypertensive patients. In the diabetic group there is always a different theme for us to address, and membership is growing. This group of diabetics is usually coordinated by the nurse, but she asks for help from other professionals, we do in the community. The major focus is on insulin-dependent, but they also have the chronic ones, the hypertensive that comes to clarification. We think about calling more people to be exchanging ideas. (DCS 3)

Central idea D: Characteristics of my work

Nowadays this part of promotion is lacking, we end up being swallowed by the system, we want to change that a bit, because we work in the family health program. And we have already started this process through a comprehensive approach 
of the individual, we have conditions to know it and to do all the health part of the family. We are always monitoring the issue of comprehensiveness, referral flows. The staff is well tuned, doing a multiprofessional work, referencing them to have strengthened the team. We were able to offer at least one access with a listening, despite the population surplus and under-sizing of teams. In groups, the work is together, it is not my only job, but it is together with the team. We worked hard with the NASF, with them we do matrix, in the same meeting I can discuss the case and guide the actions. (DCS 4)

\section{DISCUSSION}

Some studies reveal the feminization of the professions, a trend in the health area, and consequently in the PHC. Some reasons have pushed women into the labor market, including raising the level of schooling and education, reducing fertility rates, and economic changes in the country that have led to an open labor market for women ${ }^{(14-15)}$.

Regarding educational level, the 23 nurses have some type of Graduation, being the lato sensu type, which are the specializations, the ones with the highest frequency (21). Professional qualification was also found in other studies, in which the presence of a large number of professionals with some type of Graduate degree was observed ${ }^{(15-16)}$. This situation may be related to the strategy that the Ministry of Health has been using, which is to favor professional qualification, in order to strengthen policies in the public sector ${ }^{(15)}$.

Regarding the age of the participants, the age group from 31 to 35 years old was the one that was most observed, being this one considered young. One of the points that justifies this finding is the changes that have taken place in the curricula, which emphasize professional qualification to meet $\mathrm{PHC}^{\prime}$ s demands ${ }^{(15)}$.

The time of performance between six and 15 years was greater, making a total of 14 professionals. This data draws attention because it demonstrates the presence of professional experience in the PHC, which presents itself as the preferred entry point for the health care network. In addition to this practical experience, the professional qualification stands out, since all the participants of the study have some type of postgraduate course, be it lato sensu or stricto sensu.

When nurses were questioned about their work with people with NCDs, they were unanimous in responding to three practices: home visit, individual care and collective care, in addition to some to characterize them from the point of view of health promotion.

A study about care practices developed by nurses within the PHC of the city of Rio de Janeiro refers to this finding, highlighting Nursing visits, home visits and educational activities. These practices gain important significance in this environment, because it is in the PHC that the contexts are clearly expressed through the social and cultural approach to the community. Therefore, the needs are identified on the spot, which can lead to the development of more coherent and effective care practices ${ }^{(9)}$.

The home visit (DCS1) allows knowing the living conditions of the people. The main demands in this type of care are those with NCDs, bedridden, with locomotion difficulties and elderly. Being that the focus of care is the clinical accompaniment and the activities of education ${ }^{(17)}$.
It is known that home visits are among the common attributions of all FHS professionals and that their proposal is to understand the family context through the presence of professionals in the place where they live, in addition to interact and relate to individuals in a community ${ }^{(17-18)}$.

This view on the social determinants of health, which correspond to the various factors that influence the health/disease process, provides a humanized health practice and the development of health promotion actions, based on intersectoriality and interdisciplinarity, which allows to think of a new care model for the person with $\mathrm{NCDs}^{(19)}$. Therefore, home visits present themselves as a possibility to bring health closer to families, breaking with the biological model ${ }^{(17)}$. Therefore, the nurse, when conducting the home visit as a care strategy, can develop the health promotion of individuals and families ${ }^{(20)}$.

The individual care (DCS2) developed by the nurses to people with NCDs is concretized in the Nursing appointment, which is a private action of the nurse, according to the documents that regulate the Nursing profession, namely Law no. 7,498, of June 25, 1986, and Decree 94,406, June 8, 1987(21-22). At appointments, nurses emphasized the practice of health education as one of their main actions, a tool that allows the development of a work that values the human being beyond the biological part, seeking the social, emotional and spiritual side ${ }^{(23)}$.

However, it was noted in this study that health education is very much based on the lifestyle issues of people with NCDs, emphasizing healthy eating and the use of uninterrupted medications. It is known that these individuals need a continuous follow-up in PHC, since their situation demands changes in behavioral habits ${ }^{(24)}$.

Therefore, educational work should awaken in people the awareness of self-care, allowing reflections on possible attitudes for their development, and promote reflection and understanding of the subjects on the causes and consequences of their health status $^{(23)}$. Therefore, it is necessary to encourage the autonomy of individuals and communities, through the promotion of health, so that they can exercise independence on their health ${ }^{(25)}$.

In turn, the Nursing appointments are carried out in a spontaneous and programmed manner, which meets the requirements of the National Primary Care Policy (Política Nacional de Atenção Básica). The spontaneous demand corresponds to the care needs in which there is no scheduled service, whereas the scheduled demands correspond to the actions that are scheduled previously ${ }^{(18)}$. In addition, the municipality of professionals recommends, through the PHC Services Portfolio, that the agendas should have, on average, $50 \%$ of the vacancies destined to the spontaneous demand, preferably linked to the FHS team, in each opening shift of the unity ${ }^{(26)}$.

However, one of the challenges of the FHS nurses is the overload of work, caused mainly by the organization of spontaneous demand. This may end up hampering the development of actions such as health promotion, disease prevention and home visits ${ }^{(2)}$. On the other hand, their care has the potential to improve the quality of care, since PHC professionals are familiar with their health history and have a relationship with the population of their territory ${ }^{(27)}$. Thus, it is necessary to organize the work process in order to integrate the programmatic and spontaneous actions, to 
program and to develop the activities of health promotion, prevention of diseases and, at the same time, to prioritize the solution of the most common problems, considering the responsibility of the resolution assistance to spontaneous demand ${ }^{(28)}$.

Another positive point that emerged was the presence of interdisciplinary work, especially between nurses and physicians, through appointment. This is a light technology that facilitates and enhances the comprehensiveness of health services, which is achieved through dialogue and lifelong education among the members of the teams, and has been used as the main instrument of matrix support ${ }^{(29)}$.

Finally, a matter to be highlighted is the publication by the Nursing Protocol Office Health (Secretaria de Saúde do Protocolo de Enfermagem) for the care of people with hypertension and diabetes. For the participants of the study, this protocol allowed them a more targeted care and with greater autonomy in the care of these people. Clinical protocols are important for the health system, since they allow to standardize the clinical conducts based on the best scientific evidences, in order to promote protection of the professionals who are involved in care, besides a better assistance to its population ${ }^{(30)}$.

In the group care (DCS 3), the groups have been shown as a possibility of educational practice, used by the nurse in $\mathrm{PHC}$. By therapeutic group, it is understood as being a group of people who have similar problems and who come together to exchange experiences, knowledge and acquire new skills in search of a better quality of life. This modality, therefore, allows an empowerment of knowledge, discussions, criticism and the construction of healthy practices, through the practice of health education ${ }^{(3)}$.

In the present study, the health education, in the group sessions, presents itself in a constant way. However, it has been approached through lectures and pre-defined themes, which makes us think of a banking education and that often does not stimulate critical reflection, and may in many cases justify the emptying of the groups, as well as the non-performance of this practice, in the work routine of these professionals, who often have difficulty mediating a group activity.

Other research on activities developed in health education groups also revealed that participatory strategies occur less frequently than traditional ones. In addition, this type of approach, through lectures, produces low adherence of people to services, generating frustrations in professionals and, consequently, suspension of the practice of care $^{(31)}$.

The nurses reported that during the group sessions the delivery of blood glucose tapes is performed; examination of the feet and others. This finding is in line with the results found in another study, which also noted an emphasis on the technical dimension of care within educational activities ${ }^{(9)}$. This observation may be related to the technological advance that contributes to a care focused on technical procedures, influenced by the traditional model, which provides mechanistic and fragmented care practices, which prioritize curative actions. This finding runs counter to what advocates health promotion, which is based on a holistic conception, intersectoriality, empowerment, social participation, equity and actions on the social determinants of health ${ }^{(32)}$.

It is important to highlight that it is also possible to observe the presence of groups that are distant from the logic of the biomedical model, observed by the description of integrated participants and with a link with the team. In health education practices, there must be a knowledge exchange among its members. The development of the practice of popular education presupposes openness, readiness to listen to the other and horizontality in relation and educational action ${ }^{(3)}$.

An important characteristic that was observed in this study is the marked presence of inter and multidisciplinary practice, especially among the members of the Family Health Support Center (NASF- Núcleo de Apoio à Saúde da Família). However, in some cases, it was noticed that the nurse's presence was subtly displayed in the development and participation of the groups.

Teamwork in the health sector is extremely relevant, considering the complexity that configures the problems of individuals, and in particular that of people with NCDs. In this way, teamwork enables a more complete and comprehensive approach to the population, as well as a reorganization of the work process, by allowing the exchange of knowledge, union and the search for the same result and commitment to health ${ }^{(33)}$.

Most of the groups, in which nurses were responsible for designing and conducting, were performed in conjunction with other professionals. The most cited groups were for people with diabetes, especially insulin-dependent; group, in which people with hypertension were usually included. It is evident that the groups are in line with the proposals of topics suggested by the Ministry of Health, through national policies for mental health care, and orientation and prevention campaigns on how to live a healthy life and maintain habits of promotion and health, through topics such as smoking, diabetes, hypertension and healthy eating. It was also observed that people with NCDs have a wide range of group activities at their disposal, some of them more directed to the problem of chronic disease, others to health promoting practices. Unfortunately, in some situations the groups were not routinely performed, that is, they only complemented the need of the health center.

Regarding the characteristics of the work (DCS 4) described by nurses, this study highlights some important points present in the daily practice of this professional, such as: teamwork, inter and multidisciplinary, bonding, ease of access to health services, completeness of care, continuity of care, expansion of the nurse's clinic. Based on these assumptions, it is briefly understood that promotion practices are characterized by a holistic conception, by intersectoriality, by favoring community empowerment and social participation, by the search for equity, through actions on the social determinants of development of sustainable and multi-strategic actions ${ }^{(32)}$.

Although nurses already signal a new way of thinking about health, in addition to the absence of disease, it is still possible to note the presence of some labels, such as the use of terms such as "hypertensive", "diabetic", "respiratory", and "patients". That is, it is observable the presence of different discourses at certain moments of the speech, notable for the description of the presence of some practices effectively promoting health, but it is also possible to note the interference of the biomedical paradigm permeating, as a background these practices, since it is difficult to break this model of hegemonic attention in health services. 


\section{Study limitations}

As a limitation of the research, it is pointed out the restriction of the number of participants, 23 nurses. When using the DCS methodology, in addition to knowing what the collectivities think, it is possible to generalize the results found for the entire population; however for this study it may not be possible because of this restriction.

\section{Contributions to Nursing}

As a contribution, the research presents, through a scientific method, the practices of care carried out by nurses, in their daily lives, with people with NCDs, and how this presents itself in the development of health promotion within the $\mathrm{PHC}$, gateway for SUS. Thus, the consolidation of scientific knowledge is promoted, it enriches the reflections for the development of future work, so that the view can be broadened and, mainly, it allows that this knowledge can be used and reflected in the professional practice of each nurse, which has been pointed out as the best possibility in the confrontation of the NCDs, and through this expanded view of the health/disease process one can seek more and more quality care.

\section{FINAL CONSIDERATIONS}

Among the results found, three practices performed by nurses were highlighted: home visit, individual care and collective care.
It was possible to identify that nurses perform a welcoming, comprehensive practice and that consider the social determinants of health as: access to health services, health education, clinic expansion, and inter and multidisciplinary work.

On the other hand, health education was also based on guidelines for changes in lifestyle, group practices with low participatory methodology, composed of technical procedures and the use of some labels in the treatment with people with NCDs. Clinical appointments were developed much more by spontaneous demand.

These inferences lead to the reflection of the transition process and/or coexistence of two paradigms, the biomedical/ traditional and the health promotion. That is, at the same time that we observe broader behaviors, thinking about the positive concept of health and the person as a whole, we also perceive more technical actions. Therefore, it is necessary to instill the professionals to develop more extended practices, which are already part of their work process, but not always continuously.

Finally, this research demonstrates the diversity of nurses' performance and how they have been present in $\mathrm{PHC}$ and in the lives of people with NCDs. It is necessary to advance, in some points and in some shortcomings, mainly in what refers to the essence of its practices, that is, the coexistence of the biomedical/traditional paradigms and the health promotion. However, it is possible to see how this professional already makes the difference, for the quality of his practice of care.

\section{REFERENCES}

1. Melo LM, Wernet M, Napoleão AA. Atuação do enfermeiro a pessoa hipertensa na estratégia de saúde da família: revisão integrativa. Cuidarte Enferm[Internet]. 2015[cited 2017 Sep 25];9(2):160-70. Available from: http://fundacaopadrealbino.org.br/facfipa/ner/pdf/ Revista\% 20CuidArt\%20-\%20Jul\%20-Dez\%202015.pdf

2. Caçador BS, Brito MJM, Moreira DA, Rezende LC, Vilela GS. Being a nurse in the family health strategy programme: challenges and possibilities. Rev Min Enferm[Internet]. 2015[cited 2017 Sep 25];19(3):612-19. Available from: http://www.revenf.bvs.br/pdf/ reme/v19n3/en_v19n3a07.pdf

3. Mazzuchello FR, Ceretta LB, Schwalm MT, Dagostim VS, Soratto MT. A atuação dos enfermeiros nos Grupos Operativos Terapêuticos na Estratégia Saúde da Família. Mundo Saúde[Internet]. 2014[cited 2017 Sep 25];38(4):462-72. Available from: https://www. saocamilo-sp.br/pdf/mundo_saude/155566/A11.pdf

4. Guedes NG, Moreira RP, Cavalcante TF, Araujo TL, Lopes MVO, Ximenes LB, et al. Nursing interventions related to health promotion in hypertensive patients. Acta Paul Enferm[Internet]. 2012[cited 2017 Sep 25];25(1):151-6. Available from: http://www.scielo.br/ pdf/ape/v25n1/en_v25n1a26.pdf

5. Alves CG, Morais Neto OL. Trends in premature mortality due to chronic non-communicable diseases in Brazilian Federal units. Ciênc Saúde Colet[Internet]. 2015[cited 2017 Sep 25];20(3):641-54. Available from: http://www.scielo.br/pdf/csc/v20n3/14138123-csc-20-03-00641.pdf

6. Malta DC, Gosch CS, Buss P, Rocha DG, Rezende R, Freitas PC, et al. Doenças Crônicas Não Transmissíveis e o suporte das ações intersetoriais no seu enfrentamento. Ciênc Saúde Colet[Internet]. 2014[cited 2015 May 13];19(11):4341-50. Available from: http:// www.scielo.br/pdf/csc/v19n11/1413-8123-csc-19-11-4341.pdf

7. Medina MG, Aquino R, Vilasbôas ALQ, Mota E, Pinto Jr EP, Luz LA, et al. Promoção da saúde e prevenção de doenças crônicas: o que fazem as equipes de Saúde da Família? Saúde Debate[Internet]. 2014[cited 2015 May 12];38(Sp):69-82. Available from: http://www.scielo.br/pdf/sdeb/v38nspe/0103-1104-sdeb-38-spe-0069.pdf

8. Lopes MSV, Machado MFAS, Barroso LMM, Macêdo EMT, Costa RP, Furtado LCS. Promoção da saúde na percepção de profissionais da Estratégia de Saúde da Família. Rev Rene[Internet]. 2013[cited 2015 May 12];14(1):60-70. Available from: http://www.redalyc. org/articulo.oa?id $=324027985008$

9. Acioli S, Kebian LVA, Faria MGA, Ferraccioli P, Correa VAF. Care practices: the role of nurses in primary health care. Rev Enferm UERJ[Internet]. 2014[cited 2017 Sep 20];22(5):637-42. Available from: http://www.e-publicacoes.uerj.br/index.php/enfermagemuerj/ article/view/12338/12290 
10. Lefèvre F, Lefèvre AMC. O discurso do sujeito coletivo: um novo enfoque em pesquisa qualitativa (desdobramentos). 2th ed. Caxias do Sul: Educs; 2005.

11. Lefèvre F, Lefèvre AMC. Depoimentos e discursos uma proposta de análise em pesquisa social. Brasília: Liver Livro, 2005.

12. World Health Organization-WHO. The Ottawa Charter for Health Promotion [Internet]. Ottawa: WHO; 1986 [cited 2017 Sep 20]. Available from: http://www.who.int/healthpromotion/conferences/previous/ottawa/en/index1.html

13. Rodrigues CC, Ribeiro KSQS. Promoção da Saúde: a concepção dos profissionais de uma unidade de saúde da família. Trab Educ Saúde[Internet]. 2012[cited 2016 Mar 2];10(2):235-55. Available from: http://www.scielo.br/pdf/tes/v10n2/04.pdf

14. Corrêa ACP, Araújo EF, Ribeiro AC, Pedrosa ICF. Perfil sociodemográfico e profissional dos enfermeiros da atenção básica à saúde de Cuiabá - Mato Grosso. Rev Eletron Enferm[Internet]. 2012[cited 2016 Dec 3];14(1):171-80. Available from: https://www.revistas. ufg.br/fen/article/view/12491

15. Costa SM, Prado MCM, Andrade TN, Araújo EPP, Silva Jr WS, Gomes Filho ZC, et al. Perfil do profissional de nível superior nas equipes da Estratégia Saúde da Família em Montes Claros, Minas Gerais, Brasil. Rev Bras Med Fam Comun[Internet]. 2013[cited 2017 Sep 20];8(27):90-6. Available from: https://rbmfc.org.br/rbmfc/article/view/530/552

16. Lima CA, Marinho LM, Caetite LC, Ribeiro CDAL. Atributos da Atenção Primária: perspectiva e perfil de enfermeiros da Estratégia Saúde da Família. Rev N Min Enferm[Internet]. 2015[cited 2017 Sep 20];4(2):4-18. Available from: http://www.renome.unimontes. br/index.php/renome/article/view/90/130

17. Lionello CDL, Duro CLM, Silva AM, Witt RR. The performance of family health nurses in home care. Rev Gaúcha Enferm[Internet]. 2012[cited 2017 Sep 20];33(4):103-10. Available from: http://www.scielo.br/pdf/rgenf/v33n4/en_13.pdf

18. Brasil. Ministério da Saúde. Secretaria de Atenção à Saúde. Política Nacional de Atenção Básica. Brasília: Ministério da Saúde; 2012.

19. Taddeo OS, Gomes KWL, Caprara A, Gomes AMA, Oliveira GC, Moreira TMM. Acesso, prática educativa e empoderamento de pacientes com doenças crônicas. Ciênc Saúde Colet[Internet]. 2012[cited 2015 May 24];17(11):2923-30. Available from: http:// www.scielo.br/pdf/csc/v17n11/v17n11a08.pdf

20. Kawata LS, Mishima SM, Chirelli MQ, Pereira MJB, Matumoto S, Fortuna CM. The performances of the nurse in family health: building competence for care. Texto Contexto Enferm[Internet]. 2013[cited 2017 Sep 20];22(4):961-70. Available from: http:// www.scielo.br/pdf/tce/v22n4/en_12.pdf

21. Brasil. Lei n. 7.498, de 25 de junho de 1986. Dispõe sobre a regulamentação do exercício da enfermagem, e dá outras providências. Diário Oficial da República Federativa do Brasil. Brasília, DF, 26 junho de 1986.

22. Brasil. Decreto n. 94.406, de 08 de junho de 1987. Regulamenta a Lei n. 7.498, de 25 de junho de 1986, que dispõe sobre o exercício da enfermagem, e dá outras providências. Diário Oficial, Brasília, DF, 09 jun. 1987.

23. Roecker S, Nunes EFPA, Marcon SS. The educational work of nurses in the Family Health Strategy: difficulties and perspectives on change. Texto Contexto Enferm[Internet]. 2013[cited 2017 Sep 20];22(1):157-65. Available from: http://www.scielo.br/pdf/reeusp/ v46n3/en_16.pdf

24. Yoshida VC, Andrade MGG. O cuidado à saúde na perspectiva de trabalhadores homens portadores de doenças crônicas. Interface[Internet]. 2016[cited 2017 Sep 20];20(58):597-610. Available from: http://www.scielo.br/pdf/icse/v20n58/1807-5762icse-1807-576220150611.pdf

25. Haeser LM, Büchele F, Brzozowski FS. Considerações sobre autonomia e a promoção da saúde. Rev Saúde Colet[Internet]. 2012[cited 2017 Sep 20];22(2):605-20. Available from: http://www.scielo.br/pdf/physis/v22n2/11.pdf

26. Prefeitura Municipal de Florianópolis. Secretaria Municipal de Saúde. Carteira de serviços: atenção primária à saúde. Florianópolis: PMF/SMS; 2014.

27. Souza TH, Zeferino MT, Fermo VC. Reception: strategic point for user access to the unified health system. Texto Contexto Enferm[Internet] 2016[cited 2016 Dec 3];25(3):1-8. Available from: http://www.scielo.br/pdf/tce/v25n3/pt_0104-0707-tce-25-03-4440015.pdf

28. Tesser CD, Norman AH. Repensando o acesso ao cuidado na Estratégia Saúde da Família. Saúde Soc[Internet]. 2014 [cited 2017 Sep 20];23(3):869-83. Available from: http://www.revistas.usp.br/sausoc/article/view/88572/91459

29. Farias GB, Fajardo AP. A interconsulta em serviços de Atenção Primária à Saúde. Rev Eletrôn Gestão Saúde[Internet]. 2015[cited 2017 Sep 20];6(Supl-3):2075-93. Available from: http://www.convibra.com.br/upload/paper/2014/58/2014_58_9733.pdf

30. Almeida ER, Moutinho CB, Carvalho SAS, Araújo MRN. Report about the construction of a nursing protocol in child care in primary care. Rev Enferm UFPE[Internet]. 2016[cited 2017 Sep 20];10(3):683-91. Available from: http://www.revista.ufpe.br/ revistaenfermagem/index.php/revista/article/view/6844/pdf_9656

31. Mendonça FF, Nunes EFPA. Atividades participativas em grupos de educação em saúde para doentes crônicos. Cad Saúde Colet[Internet]. 2014[cited 2016 Dec 3];22(2):200-4. Available from: http://www.scielo.br/pdf/cadsc/v22n2/1414-462X-cadsc-22-02-00200.pdf

32. Moysés ST, Sá RF. Planos locais de promoção da saúde: intersetorialidade(s) construída(s) no território. Ciênc Saúde Colet[lnternet]. 2014[cited 2016 Mar 2];19(11):4323-29. Available from: http://www.scielo.br/pdf/csc/v19n11/1413-8123-csc-19-11-4323.pdf

33. Duarte MLC, Boeck JN. O trabalho em equipe na Enfermagem e os limites e possibilidades da Estratégia Saúde da Família. Trab Educ Saúde[Internet]. 2015[cited 2017 Sep 20];13(3):709-20. Available from: http://www.scielo.br/pdf/tes/v13n3/1981-7746tes-13-03-0709.pdf 